\title{
Knowledge Management System with Human Resource Approach
}

\author{
Sylwia Wiśniewska, PhD \\ Cracow University of Economics, \\ 31-510 Cracow, 27 Rakowicka St., Poland \\ sylwia.wisniewska@uek.krakow.pl
}

\author{
Kamil Wiśniewski, PhD \\ Jan Kochanowski University, \\ 25-369 Kielce, 5 Żeromskiego St., Poland \\ kamil.wisniewski@ujk.edu.pl
}

\begin{abstract}
The purpose of this article is to define the tasks and competencies of employees necessary to design and use the knowledge management system in the enterprise. The first part contains theoretical considerations regarding such concepts as knowledge, knowledge management, knowledge management system and competencies. Whereas in the second, author's summary of tasks and competencies of the company employees, which provides guidance for managers of companies interested in implementation the concept of knowledge management system, is discussed. Aforementioned enables an earlier creation of the development timetable for the appropriate employee competencies in response to the planned division of tasks associated with the implementation of knowledge management system. The article is based on the practical authors' experience, gained in the field of the KMS design and business consulting to business needs.
\end{abstract}

Keywords: knowledge, knowledge management, knowledge management system, human resource approach, competencies.

\section{INTRODUCTION}

Nowadays, in the age of globalization and the associated massive increase in the scale of creation and knowledge exchange, enterprises are faced with problems of all processes involving knowledge. Prompt searching of required and current knowledge, analysis of knowledge inflow to company from the environment, storing extensive knowledge resources while maintaining easy access to it or finally the protection of classified information are among the main problems. Therefore, comprehensive solutions such as knowledge management system (KMS) are in demand. The solutions that enable effective knowledge management (KM) to implement the company's strategy. The purpose of this article is to define the tasks and responsibilities of employees, which are necessary to design and use KMS in the company. The authors' practical experience gained in the KMS design as well as in business consulting to enterprises was the basis for the article.

\section{THEORETICAL BACKGROUND OF KMS}

According to A. Potocki [1] paradigm of modern management is generating and maximum utilization of knowledge. Different interpretations of the concept of knowledge are presented in the literature of the subject. According to B. Mikuła [2] currently the most frequently cited definitions of knowledge are those that define it as a confirmed belief as well as relating information with its comprehension. The first of indicated approaches was popularized by I. Nonaka and H. Takeuchi [3], who, under their theory of organizational knowledge creation adopted the traditional definition of knowledge understood as confirmed belief. Therefore they consider knowledge as a dynamic and highly humanistic verification process of authenticity of personal imagination. An example of the second approach is the definition of P.F. Drucker [4], under which knowledge is effective use of information in action, information focused on results. When defining knowledge, K. Dalkir [5] T.H Davenport and L. Prusak [6] are among those who refer to information. For the purposes of this article it is assumed that $\mathrm{KM}$ is a management concept focused on ensuring an efficient processes with the knowledge participation within the enterprise and between the enterprise and its environment, but also to support achievement of the objectives by the company and its stakeholders (see: [7], [8], [9], [10]). 
Special systems ${ }^{1}$ such as KMS are created in the enterprise to maximize the effectiveness of KM. These systems are defined in different ways, have different sets of features and are variously based on information technology. For the purposes of the article it is assumed that KMS is a combination of employees (responsible for implementation of specific tasks), instruments and knowledge resources, which, based on adopted strategy and information technology, in terms of the organizational culture, enables efficient processes involving knowledge and contributes to achieve the company goals (see: [12], [13], [14], [15]).

Development, implementation, use and improvement of KMS are associated with the execution of several tasks that require particular competence. In the professional literature employee competencies are recognized as the ability to appropriate selection, connection and utilization of knowledge and skills as well as promoting attitudes in order to efficient performance of professional tasks in accordance with the requirements of a particular work post (see: [16], [17]).

\section{The TASKS AND COMPETENCIES OF EMPLOYEeS ASSOCIATED WITH KMS}

In response to the needs of the enterprise, KMS should be designed and coordinated by a specially established KMS team, which organisation is illustrated in Figure 1. Company management personnel should designate a KMS Director, in consultation with whom a Knowledge Broker, KMS Coordinators in the organizational units of the company, and other team members should be appointed. It is appropriate that the position of team leader is the director's position, because it emphasizes the importance of team work for the entire company. For the post of Director and Knowledge Broker there is an expectation to appoint experienced staff of company department that produces the most knowledge (e.g. Research and Development), or employ experts from the field of KMS. Profitable solution is the situation when the Director and the Broker have professional experience in the company, which allows them to learn the specifics of the enterprise, its organizational structure and employees. Such a holistic view of the company is important due to the fact that KMS should cover the entire enterprise.

Having regard to the fact that knowledge is created, developed and used by people, a specialist of Human Resource Management (HRM), representing the company's human resource department should become a member of the KMS team. Moreover, due to the fact that knowledge used at the company is interdisciplinary, the KMS team should also be interdisciplinary. Accordingly, it should be composed of KMS Coordinators representing all organizational units of the company ${ }^{2}$. Depending on the requirements and company specifics the KMS team may involve employees working in various positions such as Research and Development Specialist, Occupational Health and Safety Specialist, Quality Management Specialist, Accountant, an IT Specialist, or a person in charge of marketing, sales, public relations, secretariat, a library, archives, etc. The appointed team should be entered in the company's organizational structure and report directly to the Management Board, which task will be to control its operation.

Management personnel's responsibility shall be to inform employees about the composition of the appointed team as well as ask them for openness and support for action of team members who work in the interest of entire company. This will contribute into increase of employee involvement to KM, on the basis of KMS.

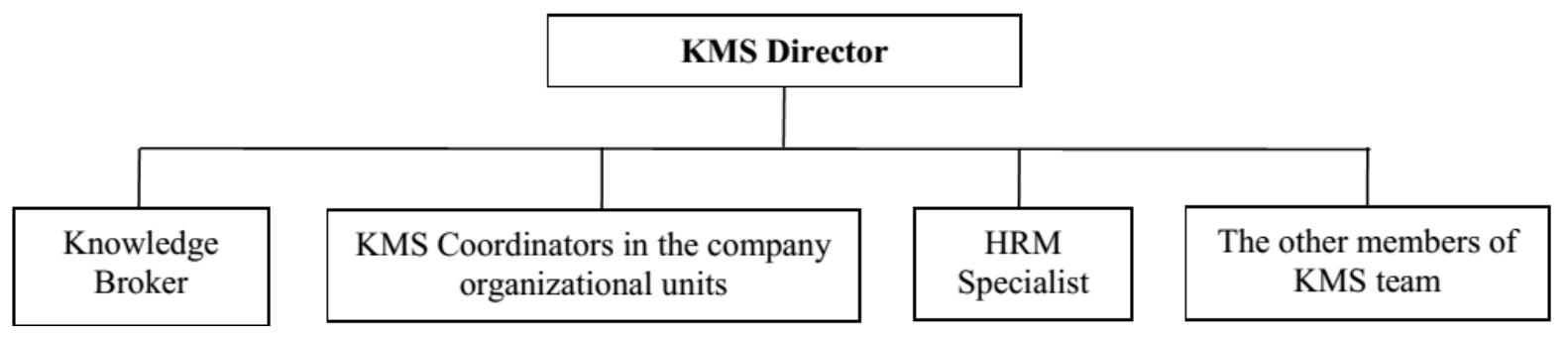

Fig1. KMS team

\footnotetext{
${ }^{1}$ The system can be seen as set of interrelated elements, separate from the environment [11].

${ }^{2}$ Depending on the company's organizational structure they can be e.g. the representatives of departments, affiliates, subsidiaries, points of sale.
} 
Individual members of the KMS team should be responsible for a number of tasks that are included in Table 1. It is worth emphasizing that the KMS Director while executing their tasks should use the support by KMS team and optionally the services of external experts. Furthermore, all KMS team members and company employees are expected to support each other in the area of working with KMS.

Table1. Company employees' tasks related to KMS

\begin{tabular}{|c|c|}
\hline $\begin{array}{l}\text { Categories } \\
\text { of employees }\end{array}$ & The tasks concerning KMS \\
\hline KMS Director & $\begin{array}{l}\text { - remaining in the constant contact with the company management, in order to ensure } \\
\text { that KM fit the needs and development direction of the company } \\
\text { - ensuring the financing of KMS team and administration of committed budget } \\
\text { - appointment of KMS team, determination its objectives and management of the team } \\
\text { - formulation and implementation of: KMS objectives, corporate knowledge strategy and } \\
\text { KM strategy } \\
\text { - emphasizing the knowledge orientation in a corporate vision and mission } \\
\text { - developing a methodology for the KMS design with the model of the system } \\
\text { - determination the principles and good KM practices } \\
\text { - comparison of KMS target model with solutions concerning KM, currently used in the } \\
\text { enterprise } \\
\text { - creating, coordinating and modifying the infrastructure for KM } \\
\text { - postulation of changes relating to the company's organizational structure, culture or } \\
\text { communication, in order to support KMS } \\
\text { - selection and implementation of instruments supporting KM, e.g. in the field of } \\
\text { information technology } \\
\text { - introduction of changes in the company, that enable to start KMS operation } \\
\text { - responsibility for the KMS operation and improvement (even on the basis of ideas } \\
\text { reported by employees) } \\
\text { - identification of indicators allowing the assessment of the KMS effectiveness and use } \\
\text { them to conduct the cyclical system diagnosis } \\
\text { - establishing and coordinating cooperation related to KM with external entities e.g. } \\
\text { entering into strategic alliances aimed at joint implementation research and } \\
\text { development projects in which the creation of knowledge forms the basis for } \\
\text { innovation } \\
\text { - motivating KMS team members to efficient work } \\
\text { - verification of own and others' ideas for KMS improvement }\end{array}$ \\
\hline Knowledge Broker & $\begin{array}{l}\text { - analysing the internal and external environment in order to diagnose gaps in corporate } \\
\text { - knowledge and taking action aimed at filling the gaps } \\
\text { - KMS administration, among others, through servicing corporate knowledge bases } \\
\text { as well as between the company and its surroundings } \\
\text { - supporting efficient processes involving knowledge, e.g. through the ongoing } \\
\text { acquisition of knowledge of the company's environment, processing it, classification, } \\
\text { codification and dissemination within the enterprise } \\
\text { - identification of employees with fundamental knowledge for the company, motivating } \\
\text { them to both, share it with colleagues and use it to achieve corporate objectives } \\
\text { - acquisition, categorization, preliminary analysis and submission of ideas concerning } \\
\text { the company's KMS improvements reported by employees, to the KMS director } \\
\text { - diagnosing and eliminating barriers related to communication and knowledge transfer } \\
\text { - noticing and satisfaction of employees requirements concerning KM, e.g. by providing } \\
\text { them the necessary knowledge } \\
\text { - codification of personalized critical knowledge that may be necessary in the future } \\
\text { - identification and protection of knowledge resources, which should not be distributed } \\
\text { outside the company } \\
\text { - minimizing the scale of loss and becoming outdated of the company's knowledge } \\
\text { - the promotion of changes related to KMS } \\
\text { - supporting the employees in KM } \\
\text { - benchmarking in the field of KM } \\
\text { - knowledge mapping }\end{array}$ \\
\hline The KMS & - making changes allowing for the KMS implementation to a specific organizational unit \\
\hline
\end{tabular}




\begin{tabular}{|c|c|}
\hline $\begin{array}{l}\text { Coordinators in the } \\
\text { organizational } \\
\text { units of the } \\
\text { company }\end{array}$ & $\begin{array}{l}\text { - responsibility for the KMS functioning in the particular organizational unit } \\
\text { - popularisation of the KMS concept among the organizational unit employees } \\
\text { - motivating the organizational unit employees to benefit from KMS } \\
\text { - relationships construction and maintaining with other organizational units of the } \\
\text { company } \\
\text { - suggesting modifications to the KMS, enabling its better adjustment to the specific } \\
\text { organizational unit needs }\end{array}$ \\
\hline HRM Specialist $^{3}$ & $\begin{array}{l}\text { - formation of working conditions that are optimal for KM and competencies } \\
\text { development } \\
\text { - determination of competence standards for existing posts } \\
\text { - identifying, attracting and employing of outstanding employees and talents } \\
\text { - taking into consideration the issue of KMS within the programs supporting new } \\
\text { employees adaptation to work } \\
\text { - employees preparation for current and future tasks } \\
\text { - planning of employee career paths in response to corporate needs regarding the } \\
\text { development of specific knowledge resources } \\
\text { - identification of a gap between personnel competencies and the competency demands } \\
\text { arising from the company's strategy } \\
\text { - providing employees with opportunities for development of competencies related to } \\
\text { KMS, e.g. in the form of training, coaching or mentoring } \\
\text { - identification and comprehensive support of talented employees as well as those with } \\
\text { key business competencies } 4 \\
\text { - considered in the context of employee assessment, their commitment to developing } \\
\text { competencies and KM } 5 \\
\text { - motivating employees to KM and commitment to improving KMS } \\
\text { - introduction of the team remuneration concept } \\
\text { - creation of employee teams (including multi-disciplinary and virtual) focused on } \\
\text { creating new knowledge e.g. the one necessary for the implementation of innovative } \\
\text { processes } \\
\text { - cooperation with external experts, former employees and entities enabling the } \\
\text { competencies development } \\
\text { - development of a outplacement system enabling conflict-free terminating of employees } \\
\text { whose knowledge does not correspond to the current needs of the company and those } \\
\text { who are not willing to develop themselves }\end{array}$ \\
\hline $\begin{array}{l}\text { The other members } \\
\text { of KMS team }\end{array}$ & $\begin{array}{l}\text { - use of their expertise for the KMS design, operation and development } \\
\text { - implementation of tasks assigned by the KMS director } \\
\text { - the provision of services related to KM for the other employees }\end{array}$ \\
\hline $\begin{array}{l}\text { All employees of } \\
\text { the company }\end{array}$ & $\begin{array}{l}\text { - cooperation with members of the KMS team } \\
\text { - involvement in KM expressed through e.g. in the proper use of the KMS possibilities } \\
\text { - participation in the processes of organizational learning, among others, by learning } \\
\text { how to learn, collective learning, drawing conclusions from the successes and failures } \\
\text { as well as learning on their basis } \\
\text { - development of organizational culture favourable to KMS } \\
\text { - participation in supporting processes of adaptation at the workplace and the } \\
\text { - development of competencies (including related to KMS) programs } \\
\text { the acquisition of knowledge through contacts with the company's stakeholders }\end{array}$ \\
\hline
\end{tabular}

To perform the tasks related to the company KMS, the appropriate competencies are necessary. According to the KMS adopted objectives, sets of these competencies may differ. The key competencies of employees of the company, relevant in the KMS context are included in Table 2.

\footnotetext{
${ }^{3}$ See: [18].

${ }^{4}$ This will help in accelerating the development of these employees and creating working conditions that minimize the risk of their leave from work.

${ }^{5}$ On the basis of this assessment, the employee should obtain feedback on the level of their knowledge and other competencies.

${ }^{6}$ This involves connecting the parts of the employee's salary with the performance of all team members. The objective is to motivate team members to share knowledge and consequently lead to a reduction in the differences between employees of the largest and smallest store of knowledge.
} 
Knowledge Management System with Human Resource Approach

Table2. Competencies of employees associated with KMS

\begin{tabular}{|c|c|}
\hline $\begin{array}{l}\text { Categories of } \\
\text { company } \\
\text { employees }\end{array}$ & Competencies related to KMS \\
\hline KMS Director $^{7}$ & $\begin{array}{l}\text { - } \text { systems design } \\
\text { - } \text { strategic knowledge management } \\
\text { - interdisciplinary knowledge concerning, i.a. the whole company and the industry in which it } \\
\text { - } \text { cherates } \\
\text { - decision-making } \\
\text { - negotiation } \\
\text { - perspective and holistic thinking } \\
\text { - setting of objectives and their consistent implementation } \\
\text { - charisma } \\
\text { - professional experience } \\
\text { - verification of operating procedures } \\
\text { - showing enterprise } \\
\text { - goal and changes orientation } \\
\text { - planning } \\
\text { - leadership abilities } \\
\text { - coordination of activities } \\
\text { - enforcement of work results from co-workers } \\
\text { - HRM }\end{array}$ \\
\hline $\begin{array}{l}\text { All members of the } \\
\text { KMS team and } \\
\text { employees }\end{array}$ & $\begin{array}{l}\text { - the practical application of knowledge } \\
\text { - general and expertise knowledge related to the work position } \\
\text { - work engagement and the development of KMS } \\
\text { - fast learning and constant development of competencies } \\
\text { - responsibility and consistency in action } \\
\text { - parallel implementation of several tasks } \\
\text { - teamwork } \\
\text { - tolerance } \\
\text { - establishment and relationships maintaining } \\
\text { - communication skills } \\
\text { - active listening } \\
\text { - networking } \\
\text { - positive attitude } \\
\text { - changes and cooperation openness } \\
\text { - analytical thinking } \\
\text { - observation } \\
\text { - creativity } \\
\text { - proactivity } \\
\text { - the use of information and communication technologies } \\
\text { - connection personal goals with the organization ones } \\
\text { - comprehension of own strengths and limitations }\end{array}$ \\
\hline
\end{tabular}

Competencies indicated in Table 2 are universal. More specific powers of individual members of the KMS team arise from their assigned tasks associated with this system. These competencies therefore are understood as necessary expertise and skills required to effective implementation of tasks related to KMS.

${ }^{7}$ See: [19], [20], [21].

${ }^{8}$ Competencies for HRM are considered, i.a., as skills related to team management, motivation and evaluation, delegation of rights, conflict resolution, planning and organizing of own and employees' tasks as well as conflict resolution. Competencies in the field of HRM are also domain of HRM Specialist, e.g. the ability to definition of competence standards for the posts, recruitment and selection, employee assessment, motivation and remuneration, training and development of employees, as well as outplacement. 


\section{Conclusions}

The lack a holistic view of the KM issues is observed in number of enterprises. Although it is difficult to imagine a company where there is no KM, even in informal form. Reflections included in article, present guidance for management personnel interested in the transition from informal to formal KM. These considerations enable to realize the scale of the tasks and responsibilities associated with KMS. This, however, can provide support for the managers in a precise division of duties relating to KMS and targeting employees on the development of competences that are essential in connection with the planned implementation of KMS. This is particularly important due to the fact that to acquisition of competencies related to KMS, specific amount of time is required. It is worth therefore, to start to develop them as early as possible. Furthermore, when planning KMS implementation, the level of competencies necessary for effective KM should be taken into consideration as a criterion in the processes for recruitment, evaluation and motivating employees. It is worth mentioning that the division of tasks associated with KMS may vary depending on the company size, the degree of internationalization of its performance, industry specifics, as well as the level of innovation. This implies further research directions enabling an allocation of tasks and responsibilities concerning KMS under the prescribed determinants.

\section{REFERENCES}

[1] Potocki A., Wybrane metody generowania i wykorzystania wiedzy w organizacji, in. B. Mikuła (Ed.), Zachowania organizacyjne w kontekście zarządzania wiedzą, Fundacja Uniwersytetu Ekonomicznego w Krakowie, Kraków, P. 63 (2012).

[2] Mikuła B., Istota zarządzania wiedzą w organizacji, in. A. Potocki (Ed.), Komunikacja w procesach zarządzania wiedzą, Fundacja Uniwersytetu Ekonomicznego w Krakowie, Kraków, P. 13 (2011).

[3] Nonaka I., Takeuchi H., The Knowledge-Creating Company: How Japanese Companies Create the Dynamics of Innovation, Oxford University Press, New York, Pp. 80-81 (1995).

[4] Drucker P.F., Post-Capitalist Society, Harper Business, New York, P. 43 (1993).

[5] Dalkir K., Knowledge management in theory and practice, Elsevier Butterworth-Heinemann, Burlington, P. 336 (2005).

[6] Davenport T. H., Prusak L., Working Knowledge. How Organizations Manage What They Know, Harvard Business School Press, Boston, P. 5 (2000).

[7] Aktharsha U. S., Anisa H., Knowledge Management System and Learning Organization: An Empirical Study in an Engineering Organization, The IUP Journal of Knowledge Management, 9(2), P. 26 (2011).

[8] Salisbury M. W., Putting theory into practice to build knowledge management systems, Journal of Knowledge Management, 7(2), P. 128 (2003).

[9] Goodman N., Schieman J., Using knowledge management to leverage training and development initiatives, Industrial and Commercial Training, 42(2), P. 112 (2010).

[10] Yaghoubi N-M, Yazdani B. O., Ahoorani N., Banihashemi S. A., Information Technology Infrastructures and Knowledge Management: Towards Organizational Excellence, Computer and Information Science, 4(5), P. 22 (2011).

[11] Becker J., Propedeutyka informatyki ekonomicznej, in S. Wrycza (Ed.), Informatyka ekonomiczna. Podręcznik akademicki, Polskie Wydawnictwo Ekonomiczne, Warszawa, P. 26 (2010).

[12] Abdullah R., Selamat M. H., Sahibudin S., Alias R. A., A Framework For Knowledge Management System Implementation in Collaborative Environment for Higher Learning Institution, Journal of Knowledge Management Practice, 6(3), P. 1 (2005).

[13] Aktharsha U. S., Anisa H., Knowledge Management System and Learning Organization: An Empirical Study in an Engineering Organization, The IUP Journal of Knowledge Management, 9(2), P. 26 (2011).

[14] Akhavan P., Jafari M., Fathian M., Critical Success Factors of Knowledge Management Systems: a Multi-case Analysis, European Business Review, 18(2), Pp. 108-111 (2006). 
[15] Murphy T., Jennex M. E., Knowledge Management and Hurricane Katrina Response, in. M. E. Jennex (Ed.), Current Issues in Knowledge Management, Information Science Reference, Hershey, Pp. 329-330 (2008).

[16] Parvu I., Ipate D. M., Mitran P. C., Identification of Employability Skills - Starting Point For the Curriculum Design Process, Economics, Management, and Financial Markets, 9(1), P. 238 (2014).

[17] Whiddett S., Hollyforde S., A Practical Guide to Competencies: How to Enhance Individual and Organisational Performance, Chartered Institute of Personnel and Development, London, P. 15 (2003).

[18] Loveday O., Role of Manager in Human Need Fulfillment in Work Organization, International Journal of Managerial Studies and Research, 2(8), P. 45 (2014).

[19] Baldonado A. M., What Can We Learn from Young Business Leaders Today?, International Journal of Managerial Studies and Research, 3(6), P. 42 (2015).

[20] Chang-zhi M., Bin H., Hong Z., Si-ying L. and Xing T., Three Dimensions and Nine Elements Structural Model of Positive Energy Leadership, International Journal of Managerial Studies and Research, 3(5), Pp. 79-80 (2015).

[21] Farahmand N. F., Organizational Systems Type Leadership by Systematic Management, International Journal of Managerial Studies and Research, 2(2), Pp. 65-67 (2014).

\section{AUTHORS' BIOGRAPHY}

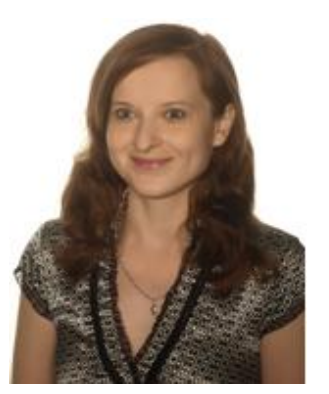

Sylwia Wiśniewska, PhD of economic sciences in management sciences, Assistant Professor at the Department of Labour Resources Management at the Faculty of Management, Cracow University of Economics. Her research interests include: human capital management, innovativeness of enterprises and innovation centres. The conducted research activity is the basis for the development of innovative solutions in the field of human capital management for the needs of business practice.

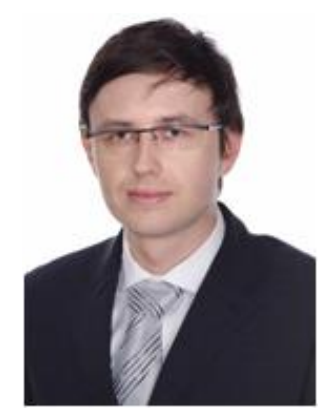

Kamil Wiśniewski, PhD of economic sciences in management sciences, Assistant Professor at the Department of Management at the Faculty of Law, Administration and Management, Jan Kochanowski University. His research interests focus mainly on knowledge management system and marketing in innovative enterprises. His research findings are applicable to business practice. 